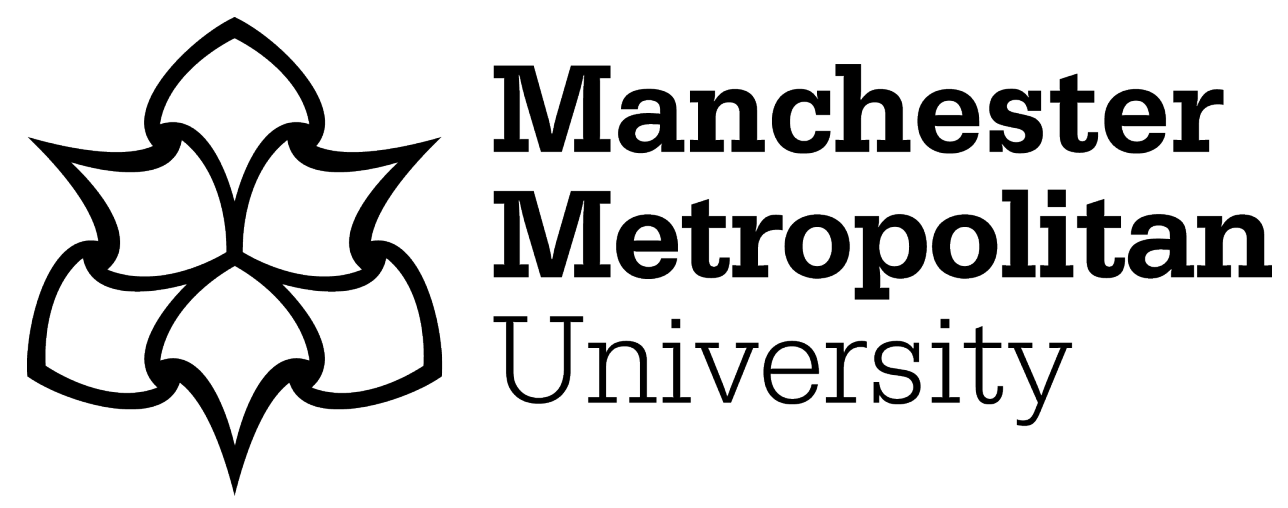

Beel, David, Jones, M and Jones, IR (2017) City-Region Building and Geohistorical Matters. In: Reanimating Regions: Culture, Politics, and Performance. Regions and Cities . Routledge. ISBN 1317395042

Downloaded from: https://e-space.mmu.ac.uk/622031/

Version: Accepted Version

Publisher: Routledge

Please cite the published version 


\title{
City-Region Building and Geohistorical Matters
}

\author{
David Beel \\ Department of Geography \\ The University of Sheffield \\ Sheffield, S10 2TN \\ d.e.beel@sheffield.ac.uk \\ Martin Jones \\ Department of Geography \\ The University of Sheffield \\ Sheffield, S10 2TN \\ martin.jones@sheffield.ac.uk
}

\author{
Ian Rees Jones \\ WISERD \\ Cardiff University \\ Cardiff, CF10 3BB \\ JonesIR4@cardiff.ac.uk
}

July 2016 


\section{City-Region Building and Geohistorical Matters}

\section{Introduction}

In an article published nearly 15 years ago MacLeod and Jones (2001), carefully reviewed, situated, extended, and above all celebrated the enormous intellectual contributions of Anssi Paasi to the scholarly project of doing 'regions in geography'. Situated within, and going beyond, the 'new regional geography' movement in human geography and the social sciences more broadly, they looked at Paasi's thinking on regionalization processes, abstracted in four stages, which collectively allowed them to advance (as they claimed) a meaningful understanding of regional change. Rolling forward the research clock to the likes of the Northern Powerhouse and other devolution events across the UK, the authors of this paper maintain that Passi's framework remains a cutting-edge theoretical framework in and through which to examine region-building processes and practices. This chapter accordingly looks at the 'new new localism' and suggests the need to now think about the dawn of a 'new new regional geography'.

\section{New New Localism}

City-Region-based agglomerations are currently riding high on the political and policy agenda across the world. Their emergence is not accidental; they are being built in direct response to the deep ideological and thinking exposed in key documents such as the World Bank's Word Development Report 2009: Reshaping Economic Geography. This set in train a series of 'new economic geography' influenced arguments closely following the work of policy-advisors such as Krugman and Glaeser (). These collectively claim that, firstly, urbanization is a global phenomenon to be embraced at all costs and within this, cityregions are the principal scale at which this happens and people experience lived reality. Secondly, somewhat provocatively, the economic basis of city-regions rests on concentration and specialization, which allows spatial agglomeration to take place. Thirdly, cosmopolitan policy management is required with a bold and confident voice, working with the grain of market logistics and new 'spatial orderings' (such as governance frameworks) to lubricate agglomeration and provide efficiency by lowering transaction costs and promoting proximity, and thereby liberating growth and allowing it to spread geographically (for an overview, see Storper 2013).

In the UK, this motif is clearly evident in interventions over the last year in the wake of RSA's City Growth Commission, which argued for the unleashing of metro growth, through a series of city-regions, or 'metros'-defined as the "larger constellation of cities and towns that constitute a functional economy within build up areas" - as the main drivers of economic growth in an increasingly knowledge-driven, global economy (RSA 2014). The UK Conservative Government, through policy discourses and narratives of devolution, localism, rebalancing, and the Northern Powerhouse, is currently taking these agendas forward as a 
response to hold-down the global and also finding a way around the messy nature of austerity and local state restructuring (see Conservative Party 2015).

The authors are currently involved in a three-year research project based of the Universities of Sheffield and Cardiff. It is probing on the missing socially and spatially disembedded sphere of these competitive relationships, equilibrating tendencies, and critically the vacuum around the policies and politics of assembling city-regions. In short, there is little research being undertaken on City-Region Building, i.e. which civil society stakeholders are involved and what the motives are for engagement or a lack of engagement. Added to this, there is no critical assessment of whether and how marginalisation (by interest groups and by geographical location) and uneven development (the relationship between regions, cities and places) operates, and in turn whether this fuels, sustains, or destroys economic agglomeration, development, and growth (Jones and Jones 2015). The project is therefore addressing this gap within the research field.

The authors are deploying case study research-based on two sites in Wales (Cardiff Capital Region and Swansea Bay City Region) and two sites in England (Sheffield City Region and Greater Manchester City Region). It involves interviews with around 20-25 stakeholders in each location-and we are currently undertaking a comparative study of stakeholder and civil society organizational involvement in the City-Region Building agenda. By focusing on the institutions of economic governance, the project is specifically looking at those involved in Local Enterprise Partnerships, various City Deals, Enterprise Zones and city-region development in general. The following research questions are being asked: what policy, strategy, and institutional changes have taken place, and are currently taking place, in the landscape of economic development since 2010 in England and Wales? How do these changes affect and involve civil society organizations? What are the narratives of devolution and community engagement in the LEPs, EZs, City Deals and City-Regions? How are these being worked into policies and procedures for stakeholder engagement? Who is involved in the new localism and how does this relate to forms of associational life and political engagement? In turn, what are the compositions of LEP, EZ, City Deal and City-Region boards, and their sub-groups and other structures of engagement? And, how successful are the City-Region Builders and the new localism in realizing the objectives of agglomeration, economic development and growth, and social empowerment?

Geographers have positioned the above as part of a 'new localist' political and policy discourse, given the arguments around the reanimation of civil society as a means of stimulating localist economic development (see Clarke and Cochrane 2013; Clark 2014). As the localism is not new though: it is a reworked policy narrative (see Peck 1995), and one that will doubtless recur again, and I prefer to note this as an instance of 'new new localism' 
(Jones and Jessop 2010). This is because the latest variant of localist thinking draws extensively on some key antecedents. According to the 'Big Society' guru, Norman, localism "is a coherent and logistical expression of a conservative tradition which goes back to the $18^{\text {th }}$ century" (Norman 2011: 201). Edmund Burke's 'little platoons' () pepper this literature and are presented as progressive enablers for a democratic form of civil society-centred economic and social policy. The Conservative's new localism, then, stresses a "three-way relationship between individuals, institutions and the state. It is when this relationship is functioning well that societies flourish. This requires each element in the triad to be active and energised in its own right ... Societies should be thought of as ecosystems" (). We would like to suggest in this short chapter that Paasi's treatise on regions increasingly allows a window into the study of such new new localist ecosystems.

\section{New New Regional Geography}

If the new regional geography (Gilbert 1988) was launched to capture a coalescing concern with local responses to capitalist processes, cultural identifications, and identifying the region as a medium for social interaction, then Anssi Paasi's has clearly gone well beyond this; hence the suggested label of a 'new new regional geography'. As noted previous (MacLeod and Jones 2001), Paasi (1986: 110) sought to transcend the dualism between Marxism and humanism by seeing regions "not as static frameworks for social relations but as concrete, dynamic manifestations of the development of a society". Areal extent though is a misnomer, as regions are to be analyzed reflexively within the context of their very cultural, political, and academic conception (Paasi 1991, 1996, 2010). Notions of institutionalization come into play here, which is not a short-hand with the study of institutions; instead, attention is paid to geohistorical socio-spatial processes during which territorial units emerge as part of the spatial structure of a society and become established and clearly identified in different spheres of social action and social consciousness. They are at once lines on the map and also geographical reference points in popular and political culture. This is operationalized through a methodology of abstraction: abstract to concrete and simple to complex in the identification of phenomenon (cf. Brenner et al 2003; Sayer 1992).

\section{Stage 1}

Paasi has deconstructed the regionalization process by abstracting four stages, which rather than implying a linear sequence, of course, are to be understood as mutually constituting, reciprocal and recursive processes of structuration only distinguishable from each other analytically for the purposes of grounded research, hence why they are abstractions. The first of these concerns the assumption of territorial awareness and shape, where a territory assumes some bounded configuration in individual and collective consciousness and becomes identified as a distinct unit in the spatial structure of society. At the heart of this 
stage one can point to a series of struggles relating to cognitive mapping and the hegemony of one geographical imagination over others, the politics of scale, difference, identity and subjectivity, and the stretching and bounding of power relations (MacLeod and Jones 2001).

Rolling things forward, this clearly connects with the drawing of, and designation of, the city-region boundaries of Sheffield, Manchester, Swansea and Cardiff noted above, where power-holding actors in a territory (or outside it even) have defined and symbolized the spatial and social limits of membership and create the discourses and practices for inclusion and exclusion, to the extent that territorial shaping refers not only to the creation of boundaries but also to their representation, to their roles both as social institutions and symbols of territory. Relatedly, territorial awareness and shape can be used to shine light on the ongoing and somewhat cul-de-sac debate in English-speaking human geography on territorial (seemingly bounded) versus relational conceptions (networked and mosaic) notions of space and statehood (see Jones and MacLeod 2011). The illuminated perspective is that these processes are co-constituted: not either/or but and/both, and the balance between them depends on institutionalization practices and the balance and roles of those actors involved and their geographical dependency (see Jones and Paasi 2013, 2015; Paasi 2010, 2013; also).

\section{Insert here}

\section{Figure 1 Sheffield City Region}

In following Paasi's first stage, Figure 1, highlights well both the bounded, mapped nature of producing city regions but also the ways in which this can be contested. The city region as a whole is largely based upon what it termed the functional economic area surrounding Sheffield which in turn focusses upon commute work patterns and employment opportunities. This represents the city region as whole but as figure 1 suggests, this is far from simple when trying to create a contiguous city region. Here the economic geography of the region has been contested by the cultural and historical identities of the different Local Authorities. This means that only Chesterfield and Bassetlaw (Derbyshire and Nottinghamshire originally and respectively) have chosen constitute the SCR and be part of the 2017 Mayoral elections whereas the others have chosen to wait for a future devolution deal with their historic county regions. In Chesterfield, these overlapping senses of regionality became set against the regionalization of the city region within the context of austerity. The following letter represents geohistory of Derbyshire in Chesterfield:

What on earth is our council thinking? Chesterfield is in Derbyshire. What a plan, live in Derbyshire and be controlled by Sheffield...I do hope, fingers and toes crossed, they choose the Derbyshire and Nottinghamshire path (Derbyshire Times Letters March 3rd 2016). 
Whereas the response from the Chesterfield Borough Council took a different approach choosing to follow the potential offer of the city region, emphasising the economic necessity of the decision:

Full membership would align with Chesterfield's economic geography and provide opportunities for new and existing businesses on a footprint that makes sense to them...Chesterfield would be able to benefit fully from the two existing SCR devolution deals, including the $530 \mathrm{~m}$ p.a. additional funding over 30 years, and continuing negotiations with government for further devolution (Chief Exec. Unit, 25th Feb 2016).

Therefore, the cognitive mapping and the economic hegemony of the city region is disrupted by the pre-existing geohistory, this in part contests the processes of regionalisation in play with by SCR. It causes the SCR to split, as Figure 1, highlights creating an uneven geography moving forward.

\section{Stage 2}

For Paasi, of course, this leads on the second stage, the formation of the conceptual and symbolic shape of regions, which is neither pure nor uncontested but is instead subject to continuous negotiation, translation and a hybridity of cultural expression. That said, power holding elites will endeavor to press that such negotiations and translation manifest in a hegemonic territorial grid of meaning whereby only a selection of invented traditions, histories, and remembrances are established and creatively implicated in the constitution of a territory's social relations. Paasi's work mentions the importance here of power-laden symbols such as cartographies, flags, memorabilia, histories etc. (Paasi 1996, 2013), but in relation to my research on city-regions, attention is also drawn to the very naming of a region, which helps to connect its image and place consciousness both of insiders and of outsiders. The case of city-region building in South Wales is important in this regard.

In 2011, the Welsh Government established a task and finish group in to consider the potential role of city-regions in future economic development. The task was to decide, on the basis of objective evidence, whether a spatially focused city-region approach to economic development, as opposed to the (national) Wales Spatial Plan, could deliver an increase in jobs and prosperity for Wales. Drawing on evidence mainly from Europe and North America, three arguments for adopting a city-region approach were made: improving the planning system; improving connectivity; and driving investment through a stronger and more visible offering from an agglomerated wider region (see Jones et al. 2015). Two distinctive city-regions were proposed - the South East Wales City Region and the Swansea Bay City Region - with the proviso being that all this has to be about creating urban engines and power-houses of growth by harnessing the beneficiaries of transport, housing, inward investment and funding opportunities. In following Paasi's tract, the South East Wales City Region naming history is illuminating as over time it has morphed to being called the Cardiff Capital Region (see Figure 2 below). 
Inert here

\section{Figure 2 - Cardiff Capital City Region branding}

This was initially to purposefully distinguish Cardiff from neighbouring Newport for external promotion purposes, then later to the full renaming of the city region in order to acknowledge both capital city power status and the stretched-out variegated geography of city-region building. This points to a metro centric focus upon Cardiff, as the agglomerative centre to the region, and highlights the way in which city region governance is funnelled with regards to the future growth of the city region.

\section{Stage 3}

These processes are constituted in particular structures of expectation, themselves critical in facilitating the third stage, the emergence of institutions, where Paasi sought and still seeks to capture the identity-framing vehicles of education, law, local politics, and organizations rooted in civil society (local media, working clubs, arts and literature organizations), as well as informal conventions such as economic ties or proximity and social mores. The entrenchment of these processes into the spatial matrix of society can also foster symbolic shape. For example, as more city-regional scale organizations are instituted into an activity such as economic development, the very consciousness of some place-based agendas may be intensified (MacLeod and Jones 2001). All of which helps in providing an effective means of reproducing the material and mental existence of territories in question.

This, again, closely connects to the city-region research agenda noted above, particularly the roles played by key activists (either those involved or outside the representational institutional governance structures of the four city-regions) in colouring the territorial consciousness and at the same time reproducing the very power assigned to such institutional roles. Indeed, for Paasi $(1986,1996,2013)$, it is the institutions of a territory (and associated infrastructural power as state theorists would put it) that eventually become the most important factors in the macro-reproduction of the region. Within the context of England, there has been attempts to create new soft spaces of governance (Haughton et al., 2013) for city regions through the creation of Local Enterprise Partnerships (LEPs). These have sought to bring business into the processes of producing a growth coalition for the city region. It strategically places economic interest at the centre of the regionalisation process framing the way in which sub-national devolution and growth will take place. Within the context of city regions, this can make LEPs powerful institutions that enable business elites to have a stronger voice whilst at the same time pushing other voices to the periphery:

Trickle down doesn't work for the most vulnerable and disadvantaged and you have to have strategies around social regeneration (for want of a better word) alongside economic regeneration. Those two things should come together and I don't think they do because the LEP is very purely focused on the economic policy... Feels like I'm 
in a rowing boat and my colleagues are in a rowing boat and we're trying to turn round this big tanker (Interview 1, Sheffield, 2015).

The local civil society actor in the quote above highlights how the governance structures and actors involved in the Sheffield City Region shape the processes in a purely economic direction. This means two things for the respondent: one, it fails to address the social problems existing in the city region and two, the civil society actor has little voice in addressing this through the current structures of governance put in place. Hence, a place based agenda for growth is intensified which territorialises the strategic interest of the LEP towards an agglomerative growth model, as it reshapes the representational regime of the city region (Jessop, 1990; 2016).

\section{Stage 4}

Every theory has its limitations and previously MacLeod and I (MacLeod and Jones 2001) noted it was only fair to acknowledge that Paasi key research objective has been to uncover the more localized or bottom-up articulations involved in the reproduction of sociospatial consciousness and regional shaping of society (though see emerging research on spatial planning, Paasi 2013; Paasi and Zimmerbauer 2015). The final stage in this latter process concerns the establishment of a region in the spatial structure and popular consciousness, where it assumes the form of an institutionalized 'territorial unit' and as an identifiable constituent in the regional division of society. In practical terms, the region is ready to be mobilized for such purposes as place marketing or as a weapon in an ideological struggle over resources and power. Further if provided with administrative status, it comes to assume the material expression of the end to which state power is applied (Paasi 1991). The last year in England demonstrates the relevance of Paasi's thinking. The full map of Local Enterprise Partnerships (LEPS) is now complete, is becoming embedded, and is now being superimposed by further voluntary arrangements of local authorities through City Deals and Local Growth Deals with government and proposals for devolution to five initial (indirectly elected but legally-recognized as strategic coordinating bodies) Combined Authorities. Whilst the result is complex, these point towards the endurance of a de facto city region scalar and institutional fix. Indeed, each of the three main political parties appears to be wedded to such a fix, subject to proposing modifications. The South Yorkshire Sheffield City Region (SCR), which straddles the 'traditional' administrative geography of counties and regions and internalizes a new scale of policymaking, is becoming an established region. As part of the 'Northern Powerhouse' movement, which has been emerging in the past 12 months as a means of addressing austerity and rebalanced development, Sheffield has recently secured a deal with the UK Government to transfer more powers over transport, housing and economic growth to the city region. The Sheffield city devolution deal, only the second to be agreed in England, although not involving additional money, is being presented as a shift in power from Whitehall to the Combined Authorities in the region. This will include responsibility for the majority of the adult skills 
budget, greater control over transport schemes and greater power to decide which assets to sell for development (HM Government 2014).

These processes hence go against the grain of Paasi's fourth stage as a form central government localism is created not a bottom up flourishing of local and regional identity. This has significant impact to the processes of city regional regionalisation because the scalar jumps in governance from the local authority to the combined authority circumvents existing institutions, coalitions, popular identities and civil society actors working at the local authority scale:

At one point they talk about localism but if you look at regionalisation, it's huge, it's huge and actually the local voluntary community sector can't even hope to engage with, let alone deliver against that agenda. Therefore, civil society is finding itself squeezed behind/between a rhetoric that emphasises its importance but a reality which mitigates against its ability to capture the resources to deliver against that agenda (Interview 12, Bolsover, 2016).

The Bolsover respondent above highlights how the scalar change in governance marginalises both their ability to work at the local level (to address the needs of the communities they serve) and their ability to have influence upon processes of governance at a combined authority level. This is further reflected below in Cardiff also:

All of a sudden we become completely insignificant so whereas at the moment locally we can lobby quite hard and push the direction on certain things, all of that power would go away and how to influence rather than power. So that for us would cause quite a significant problem. If we start working more collaboratively with other similar organisations then great, we can form a nice little consortium and then we can retain the same level of perceived power and all will be well with the world. But it doesn't fit well with how any of us work really; we work with quite defined communities, we do quite tailored things for them. (Interview 2, Cardiff, 2015).

Whereby the responded identifies how changes in the scalar relationship to governmental structures deeply weakens their position as an actor in the local community and state. This means, that despite the language of localism being threaded through the centralised processes of devolution there is in fact a further distancing of the local from the structures of governance created by the introduction of city regions and their combined authority governmental structures.

\section{Conclusion}

In following Paasi's treatise on regions in geography, we feel this can provide (once again) fresh thinking for today, even 30 years after the original argument was put down in Fennia, and in doing so still offer powerful methodological means and conceptual tools with which to advance an imaginative and progressive understanding of regional change. In particular, as MacLeod and Jones (2001) argued previously, Paasi's geohistorial approach still provides 
much scope with which to unravel the political, economic, and cultural process that enable individual and institutional place-based biographies to coalesce in the form of a distinctive territorial unit with the overall regionalization of society (MacLeod and Jones 2001). Moreover, by placing the institutionalization process, its multiple and overlapping 'stage', and the critical role played by discourse and symbolic orderings of space at the centre of his treatise, Paasi still enables us to locate many of the complex forces at work in constructing the regionalization of society.

Further, and in the context of city-region building research, Paasi's framework permits us to problematize the reciprocal relationships that can exist between the whole gamut of institutional forms relating to economic behavior (LEPs, EZs, City-Regions Boards, Combined Authorities etc.), the politics of representation, political power geometries, scale, and identity, and the sedimentation of these practices into regions. In most accounts of cityregions, questions pertaining to the social construction of boundaries, territorial shape, and the very becoming of region and their associated institutional fixes remain hidden from view (compare Storper 2013; RSA 2014; HM Government 2014). In contrast, Paasi's stress on region building as an active and ongoing processes, rich in political strategy and cultural expression, still sanctions useful insights for researchers and regional strategies alike to uncover the very formation of economic and political life. Perhaps, then, it is time to think about a 'new new regional geography'. 


\section{References}

Brenner N, Jessop B, Jones M and MacLeod G (2004) "Introduction: state space in question" in N Brenner, B Jessop, M Jones and G MacLeod (eds) State/Space: A Reader (Blackwell, Oxford)

Clark N (2014) "Locality and localism: a view from British human geography" Policy Studies $34,492-507$

Clark J and Cochrane A (2013) "Geographies and politics of localism: the localism of the United Kingdom's coalition government" Political Geography 34, 10-23

Conservative Party (2015) The Conservative Party Manifesto 2015: Strong Leaderships, a Clear Economic Plan, A Brighter, More Secure Future (Conservative Party, London)

Gilbert A (1988) "The new regional geography in English and French-speaking countries" Progress in Human Geography 12, 208-228

HM Government (2014) Sheffield City Region Agreement on Devolution (HM Government, London)

Jones M (2004) 'Social justice and the region: grassroots regional movements and the 'English Question' Space and Polity 8, 157-189

Jones M (2013) "Polymorphic spatial politics: tales from a grassroots regional movement" in W Nicholls, B Miller, and J Beaumont (eds) (2013) Spaces of Contention: Spatialities and Social Movements (Ashgate, Aldershot)

Jones M and Jessop B (2010) "Thinking state/space incompossibly" Antipode 42, 1119-1149 Jones M and Jones IR (2015) "Spaces of new localism: stakeholder engagement and economic development in Wales and England" WISERD News 10, 13

Jones M and MacLeod G (2011) "Territorial/relational: conceptualizing spatial economic governance" in A Pike, A Rodrigues-Pose and J Tomaney (eds) Handbook of Local and Regional Development (Routledge, London)

Jones M and Paasi A (2013) "Guest editorial: regional world(s): advancing the geography of regions" Regional Studies 47, 1-5

Jones M and Paasi A (eds) (2015) Regional Worlds: Advancing the Geography of Regions (Routledge, London)

Jones M, Orford S and Macfarlane V (eds) (2015) People, Places and Policy: Knowing Contemporary Wales through New Localities (Routledge, London)

MacLeod G (2001) "New regionalism reconsidered: globalization and the remaking of political economic space" International Journal of Urban and Regional Research 25, 804-829 MacLeod G and Jones M (2001) "Renewing the geography of regions" Environment and Planning D: Society and Space 19, 669-695 
Norman J (2011) The Big Society (Buckingham University Press, Buckingham)

Paasi A (1986) "The institutionalization of regions: a theoretical framework for understanding the emergence of regions and regional identity" Fennia 164, 105-146

Paasi A (1991) "Deconstructing regions: notes on the scale of spatial life" Environment and Planning A 23, 239-256

Paasi A (1996) Territories, Boundaries and Consciousness: The Changing Geographies of the Finnish-Russian Border (Wiley, Chichester)

Paasi A (2010) "Regions are social constructs, but who or what 'constructs' them? Agency in question" Environment and Planning A 42, 2296-2301

Paasi A (2013) "Regional planning and the mobilization of 'regional identity: from bounded spaces to relational complexity" Regional Studies 47, 1206-1219

Paasi A and Zimmerbauer K (2015) “Penumbral borders and planning paradoxes: relational thinking and the questions of borders in spatial planning" Environment and Planning $A$ (forthcoming)

Peck J (1995) "Moving and shaking: business elites, state localism and urban privatism" Progress in Human Geography 19, 16-46

RSA (2014) Unleashing Metro Growth: Final Recommendations of the City Growth Commission (Royal Society of Arts, London)

Sayer A (1992) Method in Social Science: A Realist Approach (Routledge, London) Storper M (2013) Keys to the City: How Economics, Institutions, Social Interaction, and Politics Shape Development (Princeton University Press, New Jersey) 